\title{
COVID-19 Pandemic and the Future of China-Plus-One Strategy in Apparel Trade: A Critical Analysis from Bangladesh-Vietnam Point of View
}

\author{
Md. Tareque Rahaman ${ }^{*}$, Arnob Dhar Pranta1, Ovijit Chandrow ${ }^{2}$, Neloy Chandra Das ${ }^{3}$, \\ Mst. Dilruba Khatun', Md. Yasin Arafat', Walid Bin Bakhtair Sami ${ }^{4}$ \\ ${ }^{1}$ Department of Textile Engineering, Mawlana Bhashani Science and Technology University, Tangail, Bangladesh \\ ${ }^{2}$ Department of Physics, Shahjalal University of Science and Technology, Sylhet, Bangladesh \\ ${ }^{3}$ Department of Mechanical Engineering, Shahjalal University of Science and Technology, Sylhet, Bangladesh \\ ${ }^{4}$ Department of Business Administration, Mawlana Bhashani Science and Technology University, Tangail, Bangladesh \\ Email: *tarequerahaman.mbstu@gmail.com
}

How to cite this paper: Rahaman, M. T., Pranta, A. D., Chandrow, O., Das, N. C., Khatun, M. D., Arafat, M. Y., \& Sami, W. B. B. (2021). COVID-19 Pandemic and the Future of China-Plus-One Strategy in Apparel Trade: A Critical Analysis from Bangladesh-Vietnam Point of View. Open Journal of Business and Management, 9, 21832196.

https://doi.org/10.4236/ojbm.2021.95116

Received: July 5, 2021

Accepted: August 28, 2021

Published: August 31, 2021

Copyright $\odot 2021$ by author(s) and Scientific Research Publishing Inc. This work is licensed under the Creative Commons Attribution International License (CC BY 4.0).

http://creativecommons.org/licenses/by/4.0/ (c) (i) Open Access

\begin{abstract}
This research paper was intended to provide a conceptual discussion related to the newly arisen business model termed as "China-Plus-One", which deals with the practice of international trade between China and a $3^{\text {rd }}$ world Asian country. One of the key achievements of this strategy is that it encourages mutually beneficial trade across geographical boundary. Different world recognized global studies had proclaimed that the Southeast Asiatic region will be the next hotspot of textile and apparel trade due to the availability of raw materials and low paid labor force. As a result, numerous industrial groups of China are looking forward to attaining comparative business advantages by investing at another location of manufacturing in the Southeast Asia. This research paper conveyed a two-fold story. In the very beginning, it was expected to evaluate the comparative market position of the major textile and apparel trade competitors (especially China, Bangladesh and Vietnam). Later on, it analyzed the pattern of rapidly changing business situation due to competitive production factors such as labor cost, logistic support, utility cost, ease of doing business, corruption index etc. Though "China-Plus-One" strategy is a promising one, not that much study hadn't yet taken place regarding it. China-Plus-One strategy appears to be beneficial for both firms that seek to pursue it with a view to risk diversification, cost advantage, product and market diversification. The purpose of this study is to sort out the convergence or divergence of textile and apparel trade in the Southeast Asiatic region due to this business philosophy.
\end{abstract}




\section{Keywords}

China-Plus-One, Comparative Advantage, Textile, Trade, Bangladesh, Clothing Industry, Vietnam

\section{Introduction}

The industry that has been employing significant contribution to rebuild the economy of $3^{\text {rd }}$ world country's is none other than clothing (Islam et al., 2016; Rahaman \& Islam, 2021a; Harrison, 1994). It acts as a catalyst for the socioeconomic development of least developed countries like Bangladesh, Cambodia, Vietnam (Pham \& Yeo, 2018). During the closure of MFA (Multi Fiber Agreement) in 1994, it was proclaimed by several economists and global policy makers that the developing countries i.e. Bangladesh and Vietnam would lose their cost advantages to a free and competitive market condition (Adnan et al., 2020). In reality, those predictions were slightly appropriate for very few African countries. On the contrary, Asian countries such as Bangladesh, India, Vietnam, and Pakistan had achieved quite surprising economic growth by enhancing each of their global market share percentage just after the post MFA era (Ahsan, 2020). The apparel manufacturing industry requires cost advantage over its developed trade competitors. Having favor with preferential trade (GSP) since the mid-90s, Bangladesh has enjoyed duty free access to apparels in the EU countries, which gives it a very considerable advantage over its Asian competitors, such as Vietnam, Cambodia, India, Pakistan, Srilanka (Rahman, 2015). In 2013, Bangladesh was suspended from the GSP facilities of USA. This is because the apparel industries in the country had faced allegations of victimizing worker rights, work place safety and environmental sustainability (Joarder et al., 2010). Despite those narrow drawbacks, Bangladesh had successfully improved its overall scenario within the next 5 - 7 years by inducing trust factors and sustainable business policies with the major trade partners (especially buyers, retailers and fashion brands). Over the last few decades, the clothing industry of the country has achieved a very notable worth, and by 2011 , it had ranked at the $2^{\text {nd }}$ position among all apparel exporters (Ali et al., 2017). During the last six months of the fiscal year 2019-2020, Vietnam had surprised Bangladesh by positioning as world's $2^{\text {nd }}$ largest apparel exporter (Islam \& Maruf, 2014). It is high time Bangladesh started producing high-end diversified products, looked for diversified markets, trained up workers to maximize efficiency. But the recent trend of negative growth in the apparel export of Bangladesh and the increasing diversion of trade competitor Vietnam, due to the USA vs China trade war made Bangladesh worried. However, production of high-end apparels is traditionally embedded in the economy of Vietnam. In 1986, Vietnam launched a business policy named as "Economic Rejuvenation", which reforms its economy through entering the free 
market trade. The country has free trade agreements with the European Union, the Association of Southeast Asian Nations, Hong Kong, South Korea and China. However, the major market of Vietnam is EU countries, USA, Japan and South Korea. Vietnam with its diversified clothing items is enjoying the ultimate benefits of the USA-China trade war. Apart from those, China has been a key player for textile and apparel trade over the years (Hossain et al., 2013). Chinese textile and apparel export revenue, manufacturing productivity and cost advantages had increased significantly over the last few decades (Francisco, 2015). Even though the Chinese export value is experiencing a regular growth, the proportion of apparel export is now facing an inconsistent trend. Just because there is a parallel contest of it with other Asian economic competitors such as Bangladesh, Vietnam, India, Pakistan, Srilanka (Shehab, 2018). Due to conflict of interests and frequent trade wars between China and USA had forced China to look into another manufacturing and distribution area in the Southeast Asia. As a result, the researchers around the world had already found some probabilities of mutually beneficial trade between China another southeast Asian country (Setiawan, 2020). According to the general point of view of comparative advantage between two countries, either side can be mutually benefited from such type of preferential trade (Ahmed \& Mahmud, 2015). Developing countries of the Southeast Asiatic region such as Vietnam, Bangladesh, Pakistan, Srilanka should study each of their comparative advantages over Chinese apparel industry. Thus, China-Plus-One strategy can attain mutually dependable and sustainable textile \& apparel trading beyond geographical boundaries (Ali et al., 2019). The major contribution of this study is to integrate a fragmented business ideology, establishing a coherent academic framework, identifying the cost and gain of China-Plus-One strategy and sorting out the direct and indirect impacts of this strategy.

\section{China-Plus-One: Convergence or Divergence in the Southeast Asiatic Trade}

China-Plus-One is nothing but a business philosophy (see Figure 1) that not only focuses on investing only in China, but also spreading and diversifying business into some other Asian Countries. Since 1970s, China has moved forward itself into the world's one of the top manufacturers. But frequent economic changes in the country are causing shift in thought. The average wages of the Chinese workers had tripled over the course of last few decades. This is causing the manufactures to move forward outside China, where the worker wages are still very low. As China changes, production industries are being forced to adapt China-Plus-One strategy and look at other Asian countries for manufacturing. In addition, Chinese apparel industry has been facing a very prominent disruption due to the arrival of COVID-19 pandemic. The pandemic situation is forcing the manufactures, fashion brands and retailers to shut down the business temporarily. The sudden economic changes of global textile \& apparel trade 


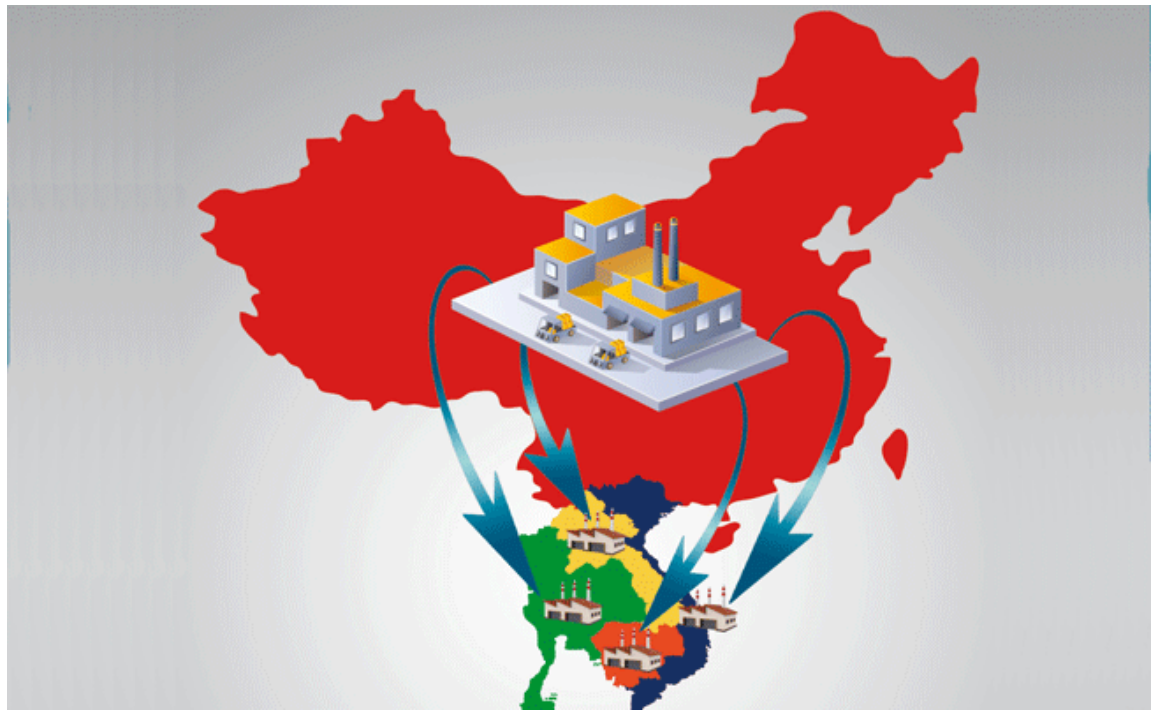

Figure 1. China-Plus-One trading philosophy.

during USA-China trade war and COVID-19 pandemic are also proposing China to take a look over China-Plus-One strategy. As a result, China's economy has been increasing interests in the China-Plus-One strategy, which encourages the application of Chinese resources to lower wage manufacturing areas of Southeast Asia (Ahmad \& Kalim, 2014). The least developed countries like Vietnam, Cambodia, Bangladesh are benefiting themselves since those early days of the USA-China trade conflict (Kukharyk, 2020). As a result, some Chinese business groups are trying to diversify both of their product and market access (Jenkins \& Sen, 2006), by sourcing another healthy business location in the Asia, where they can attain absolute advantages of low paid labor along with Chinese resources (McCann, 2011). Adapting with this model, either side can reduce its operating costs as well as enhance new market access possibilities. This trend is being driven by many factors, but the key reason is higher labor cost in China, particularly in coastal regions, those have served Chinese manufacturing industries for a long time. Besides, China is getting older and the so-called one child policy means that the experienced workers can't be replaced easily. As a result, the total workforce is declining day by day and those left are demanding more wages. Other key considerations while nominating an additional regional outpost demand logistic supports, ease of doing business, FTAs etc. In addition, leading to China-Plus-One trend towards the ASEAN countries such as Vietnam, Cambodia, Bangladesh and less credibly Myanmar are also touted as China-Plus-One candidates. But the country, which most often gets preference as alternative to China as manufacturing destination is either Vietnam or Bangladesh. The government of Vietnam is targeting to appeal multinational clothing brands and fashion houses, as it has a geographical position close to global supply chain. Other countries such as Bangladesh have its own strength too and it also successfully appeals numerous industries and fashion brands contemplating Chi- 
na-Plus-One strategy. However, Bangladesh has benefitted from the development of new trade agreements with China, which reduces tariffs on $98 \%$ of its imported items from China. This will contain a positive implication at opening up joint venture Chinese manufacturing industries in Bangladesh. The ASEAN countries, those are lack of infrastructural development and skill shortages should focus on China-Plus-One strategy. Beyond having to compete with China's strengths, these countries can potentially may get benefits from the following business model.

\section{China Plus One: Bangladesh or Vietnam}

Just after China, Bangladesh and Vietnam have been emerging as major apparel exporters in the world. And, the competition between Bangladesh and Vietnam has been enlarging day by day. The unpredictable and steady growth of both the countries have been inducing sustainable practices in textile and apparel sector. It had encouraged numerous fashion brands and corporate houses of China to establish an additional manufacturing hub outside China (Ali et al., 2019), with a view to coping up with increased labor cost in China. However, Chinese manufactures are gradually losing foreign investments due to lack of cost advantage and competitiveness in a comparison to other Asian countries (Van der Eng, 2004). The Southeast Asia countries such as Bangladesh, India, Pakistan, Srilanka are abounded with skilled and low paid labor forces and as a result, some of their manufacturing cost is lower than China. Thus, it encourages some Chinese manufactures to look into the following factors and diversify their products, production system and distribution channels by introducing another location of manufacturing (Hanson et al., 2013; Bradsher, 2008). Both Bangladesh and Vietnam are on a nail-biting position regarding apparel export, as the difference margin between them is very close. However, the business policy and environmental issues are quite different. Bangladesh is famous for its large production capacity of clothing items at a low price with acceptable quality standards. On the contrary, Vietnam usually focuses on more value added items with presence of its strong backward linkage industries and skilled workforce. Besides, a short comparison between both the countries had portrayed here (see Figure 2) to estimate the next manufacturing option of Chinese manufactures in between Bangladesh and Vietnam.

\begin{tabular}{|l|l|ll|}
\hline Sector Profile & Country Name & \\
\cline { 2 - 4 } & Bangladesh & Vietnam & \\
\hline No. of Industry & Around 4560 apparel industry & $\begin{array}{l}\text { Around 6000 apparel } \\
\text { industry }\end{array}$ \\
\hline Worker wage/month (USD) & $\mathbf{6 8 - 1 0 0}$ & $122-176$ \\
\hline Employment & Around 4 million & Around 2 million \\
\hline
\end{tabular}

Figure 2. Comparative RMG sector profile of Bangladesh and Vietnam in Year 2020-2021 (Source: The Daily Star). 


\section{Comparative RMG Sector Profile Analysis (Bangladesh vs Vietnam) from Chinese Point of View}

\subsection{Minimum Wage for Clothing Production}

The lower cost of labor reduces the manufacturing cost in a comparison to other trade competitors in the global market of textile and apparel. Bangladesh is basically a labor abounded country with low paid and semi-skilled workers. The average wages of workers vary according to the living expense, life process and working standards. Though the country has lower product diversification, it has higher production capacity in a comparison to Vietnam. The RMG workers of Bangladesh have been enjoying a steady improvement in wage board during the period of 2006-2017. Most of the worker's annual wage increment ratio is not the same in the country (see Figure 3). It is usually determined by their skill, intelligence, experiences, integrity and consistency to work in the same field (O'Connor, 2018).

On the contrary, the average monthly wage of Vietnam's garments workers is about twice that of Bangladesh and they highly rely on overtime, just like Bangladeshi textile and apparel workers. In addition, Bangladesh and Vietnam have advantages in terms of labor wage over some other countries such as Turkey, China, Thailand and Cambodia. A few recent studies had proclaimed that, about $70 \%$ of Vietnam's workers earn below global living wage. The mobility of RMG worker from one job to another one is increasing than that of previous times. Most of the cases, the workers are not satisfied with the current job. And the rapidly growing unplanned industrialization has been offering some sort of chance to rethink about the wage gap of themselves.

\subsection{Green Industry Development}

Today, some European buyers are emphasizing on green industry development, because some globally hitting burning issues like climate change and global warming have been creating awareness among the end users (Grabher, 1993;

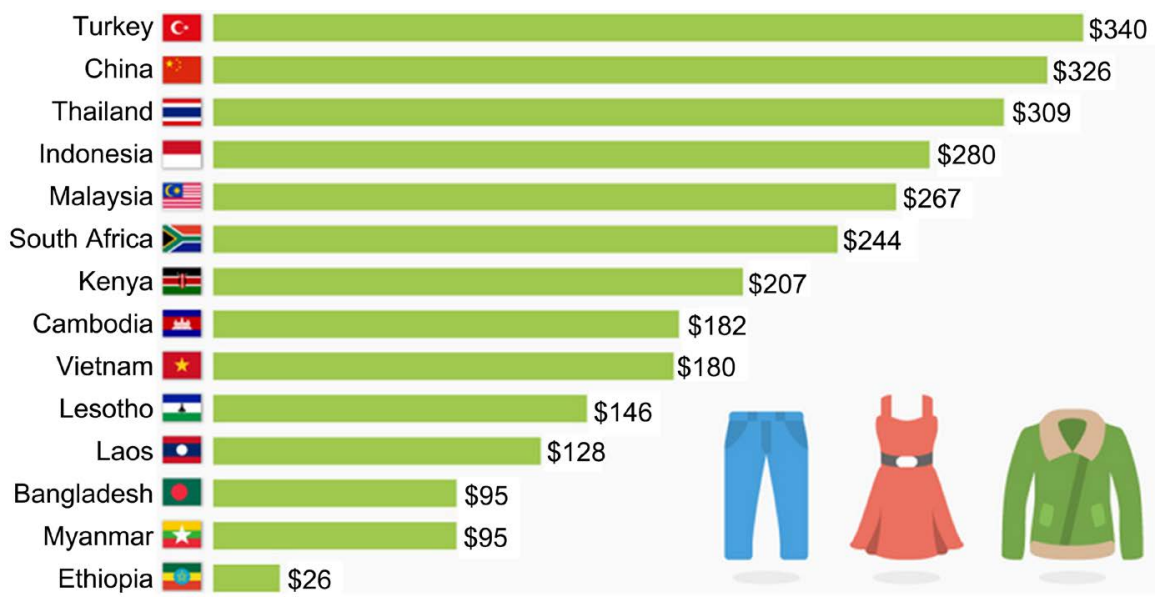

Figure 3. Low paid clothing manufacturing countries in FY-2018 (Source: Statista). 
Meyer, 2004). They are putting preference on biodegradable natural raw materials for both the manufacturing and packaging purposes. Some apparel industries of Bangladesh and Vietnam have already welcomed the newly arisen concept of using eco-friendly raw materials (organic fibers, chemicals) and socially acceptable production system. The apparel manufactures of Bangladesh are now feeling the significance of sustainability as most of the EU buyers are demanding it. They are working on it and therefore, 25 apparel industries of Bangladesh are certified as LEED platinum category by the USA Green Building Council. And, six out of the top ten LEED (Leadership in Energy and Environmental Design) platinum factories worldwide are situated in the country. Furthermore, there are 91 LEED certified green industries located in Bangladesh, which is the most among all apparel exporters. The green textile and apparel industry development is not eventually a popular concept in Vietnam till now. Vietnam only focuses on lower cost production with limited environmental standards. In a comparison to Vietnam, Bangladesh is far ahead in terms of developing sustainable green industry.

\subsection{Skilled Workforce Development}

The textile and RMG industry of Bangladesh is conducted by semiskilled workers. As a result, the sustainability and productivity of apparel manufacturing industries may be backbiting in the near future (Rahman \& Chowdhury, 2020; Maharani \& Setiawan, 2019). In 2019, with the cooperation of BEPZA, BGMEA, BKMEA and EPB and the government of Bangladesh had taken an initiative to arrange a skill development program for 1.5 million of workers. The following training program had highly focused on eliminating their communication gap between top management and middle management among the workers. Due to the absence of skilled manpower, Bangladesh has losing its cost advantage over its foreign competitors. That is why, the government has prioritized skill development programs till 2030s, just because it has still a long way to go. On the contrary, most of the textile and apparel workers in Vietnam are not only well educated but also trained enough. Apart from this, very few textile and apparel workers in Vietnam are facing some very real skill shortages and skill gaps, those are negatively affecting business across the country. However, skilled workers are the key to boosting Vietnam's apparel industry along with China-Plus-One strategy.

\subsection{Sustainable Workplace Safety Procurement}

About 7 years after the "Rana Plaza Tragedy", Bangladesh has experienced a tremendous improvement in terms of workplace safety issues in the manufacturing industry. According to the recent statistics of "Fire and Building Safety" authority of the country, about $90 \%$ of the industries have achieved pass mark in the safety check program (Kim \& Choi, 2018; Khatun \& Shamsuzzaman, 2017; Kampelmann et al., 2018). Meanwhile, the remaining 10\% are still finding ways 
in the initial remediation process. Very few deadly fire accidents including "Tazreen Fire Accident", there have been forcible improvements in terms of fire safety program in the clothing industry. As a result, the frequency of occurring industrial fire accidents is on a decreasing trend. Recently, the stakeholders and the regulatory authority proclaimed that workplace safety procurement is an everyday process, where stick monitoring and social awareness is must (DIFE, 2016; Zhang et al., 2010). On the other hand, both migrant and informal workers in Vietnam often face poor working and living conditions with low and insecure incomes, long working hours and precarious employment. In addition, many migrants and informal workers are not able to access social services such as health care and education. In a comparison to Vietnam, Bangladesh is far ahead while considering sustainable workplace safety.

\subsection{Product and Market Diversification}

Though Bangladesh is one of the leading exporters of RMG but its portion of exporting highly fashionable and value added apparel items is very low. The country has only a very limited interest in R \& D. Some studies of the last few decades also indicated that the majority of country's RMG export (almost 71\%) is restricted within USA, Japan, Cambodia and few other EU countries. According to the report of BGMEA, the highly competitive scenarios in apparel trade and frequent trade wars had caused a declined trend at 1.6\% apparel trade from 2014-2018. During COVID-19 pandemic (2019-2021), the world's demand of apparels has been decreasing day by day, which forces the manufacturers and suppliers to export at 50\% - 60\% lower prices. That's why, the RMG experts and prominent economists suggested that both product and market diversification is a must for the existence of the economy, if the country wants to explore its current lead in global apparel export, just after post pandemic situation. Bangladesh depends on five items such as men's and women's t-shirt, trouser, shirt, jacket and sweater for export while Vietnam has diversified its product line (Rahaman et al., 2021b; Hasan et al., 2021). Only in a single market, Vietnam exports 10 types of products in USA, including women's knit shirts and blouses (MMF), women's trousers (cotton), women's knit shirts and blouses (cotton), women's trousers (MMF), men's knit shirts (cotton), dresses (MMF), men's trousers (MMF), men's knit shirts (MMF), men's trousers (cotton), and women's coats (MMF). The apparel sector played a significant role in making Vietnam a rising star by generating employment, earning foreign currencies and thus contributing to the economy. While talking about both the product and market diversification, Vietnam is far ahead in comparison to Bangladesh (Ahmed, 2013).

\subsection{Lead Time and Access to Eco-Friendly Textiles}

In today's world of clothing technology, the use of eco-friendly natural and manmade fibers has been increasing day by day. A textile fiber may consider as eco-friendly, when the cultivation and manufacturing process of it doesn't in- 
clude any harmful pesticides and added chemicals. Eco-friendly natural textile fibers (cellulosic and protein) include organic cotton, jute, hemp, wool, silk etc. On the contrary, some regenerate cellulosic fiber including viscose, rayon, acetate, triacetate is also considered as eco-friendly. Nowadays the consumers of world's apparel throughout the world are more conscious about the sustainable use of textile raw materials. As some developing countries like Bangladesh are abounded with ecofriendly natural resources, the global apparel business shifting towards those. Not only the consumers but also the business owners and the government should keep eye on increasing the use of sustainable and eco-friendly raw materials for clothing industry. Vietnam's lead time is shorter because of its better infrastructure of 1900 miles of coastline and 320 ports. Besides better infrastructure, Vietnam takes shorter lead time for skilled manpower, the capacity of production and geographical location. The major textile raw material exporters such as China, Hong Kong and Singapore are its neighboring countries. On the other hand, Bangladesh takes longer lead time due to poor logistic supports (Kader et al., 2014; Nuruzzaman \& Haque, 2009).

\subsection{Gender Discrimination and Child Labor}

Gender discrimination in workplace is a very common scenario in almost every sector throughout the world. However, this practice in Bangladesh's and Vietnam's RMG industries is very pathetic among all the Asian countries. In Bangladesh and Vietnam, the majority of poverty-stricken people find opportunities by engaging themselves with manufacturing industry. The scarcity of academic knowledge is pushing them to start a job in the clothing sector as the opportunities of getting job in such industries has become quite easier from since those early years. Bangladesh produces a very cheap workforce in the RMG sector, where almost $60 \%$ of works are poor. Most of them are working mothers and they have only a few options to move forward instead of earning from the textile industry. Because of this, most of the corporate groups has been offering them low wage margin in a comparison to their male encounters. On the other hand, young women make up the overwhelming majority of workers in Vietnam's export manufacturing industries. It comprises roughly about $70 \%$ to $80 \%$ of the forced child labor. Besides sexual harassment in the clothing industry is a very common scenario. Vietnam's workers also face serious safety and health hazards on the job. In 2016, the UN Women proclaimed that $50 \%$ of the world's working age women are in the labor force in a comparison to $75 \%$ of the working age men. It also mentioned that, women earn $24 \%$ less than men, which is a very significant note of gender discrimination.

\subsection{Dependency on Raw Material Importing}

Bangladesh, the world's 3rd largest RMG exporter, badly depends on importing raw materials (especially cotton, synthetic trims and accessories) as the backward linkage industries of the country are not that much strong to cooperate 
with balance trade (Siddiqi et al., 2012). To achieve a sustainable development in textile manufacturing industry, Bangladesh needs to minimize the gap in between its import and export trade values. Despite the large domestic opportunities, the country is badly dependent on the table toppers. As Bangladesh imports a very significant amount of textile raw materials from China, it encourages the possibilities China Plus Bangladesh strategy. On the contrary, the backward linkage industries of Vietnam are very strong. It only depends on textile imports for a very margin textile raw materials including fiber, yarn, fabric, trims and accessories. While considering easier access to textile raw materials, it can easily be perceived that Vietnam is far ahead in a compression to Bangladesh.

\subsection{Next Hub of Apparel Export}

The statistics of "McKinsey apparel CPO survey 2017" had explained that Bangladesh will be the hub of apparel exports for the next 5 years. The government imposed logistic supports, financial and structural intensives had already made Bangladesh one of the most influential countries in the world's apparel trade. Apparel experts and the economists predicted that the dominance of Bangladesh in apparel market share will be enlarged over the years due to geopolitics and frequent trade wars.

Figure 4 reveals that Bangladesh is slightly ahead of Vietnam, while considering FOB facilities, pricing, tariffs advantages, production reliability and economic order quantity (EOQ). The government of Bangladesh provides some legal subsidies and financial incentives, whose encourage the rapidly growing apparel industry to explore more cost advantage. However, Vietnam is slightly ahead of Bangladesh in terms of lead time pictogram, product diversification, market access and product quality (Yunus \& Yamagata, 2012). Besides, highly organized port facilities and short distance trade sourcing partners for collecting raw materials

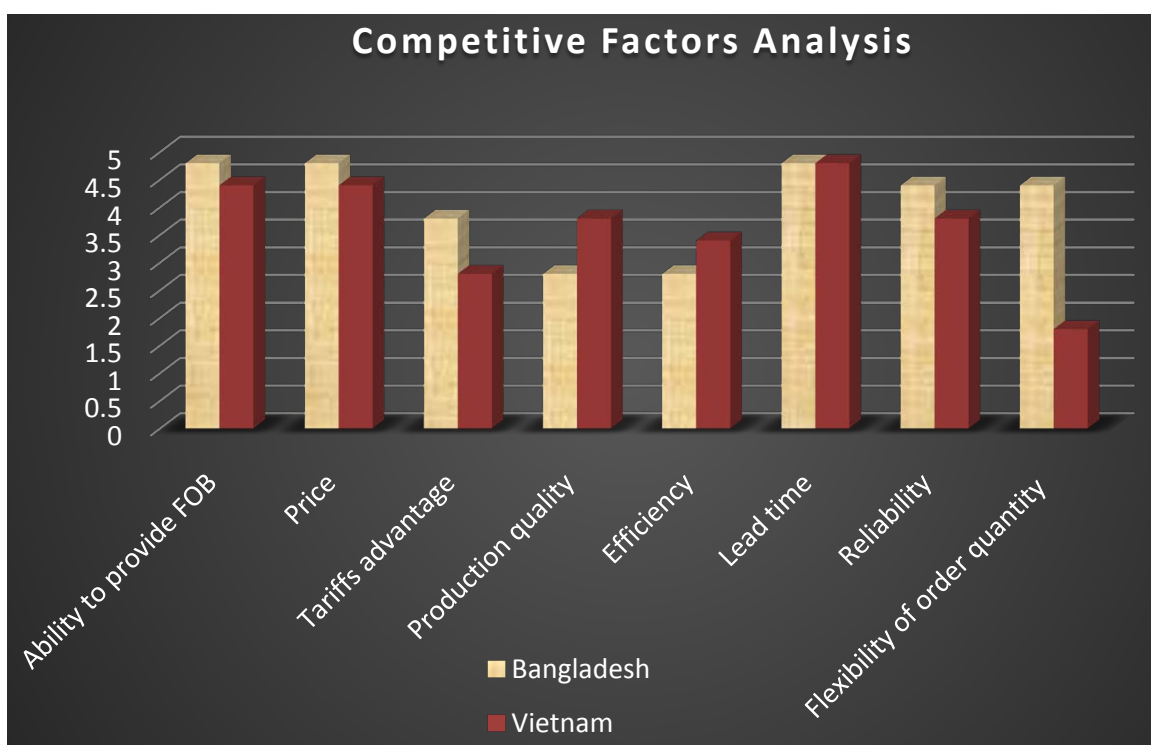

Figure 4. Competitive factors analysis. 
contain some sort of advantages for Vietnam. The following competitive factors analysis doesn't allow absolute competitive advantage to each of the following countries.

\section{Recommendations for China-Plus-One Strategy}

The manufactures of each of the Asian countries should ensure the uniformity of demand and supply chain management of raw materials and finished goods.

$>$ The government of each of the developing countries should enlarge the activates of "Import \& Export Task Force" with a view to finding new market.

$>$ The corporate house should have up-to-date information of the current scenario of the global apparel export trade.

There should have transparency and positive competitions in between trade competitors beyond geographical boundaries.

\section{Conclusion}

The summary of the following hypothesis "China Plus Bangladesh or Vietnam?" has been arising as a complex one to evaluate, just because both the countries are developing till now. Each of them has some unique strengths and major drawbacks. As China is now trying to lead the world economy, it is now focusing more on some other value-added power industries. The orders of EU countries and USA are now shifting from China to some other developing South Asian counterpart, such as Bangladesh, Vietnam, India, Pakistan. Vietnam is now attaining the benefits from TPP (Trans-Pacific Partnership), whereas Bangladesh is getting GSP (generalized System of Preference) facility from the EU countries. Bangladesh has more advantages over Vietnam regarding low paid labor force, higher production capacity and manufacturing cost advantage. In addition, Bangladesh is ahead of Vietnam, while dealing with green industry development, workplace safety and logistic supports. On the contrary, Vietnam is far ahead of Bangladesh while estimating product and market diversification, leading time facilities and easier access to raw materials. So, the analysis showed that both the countries are pretty even to even in terms of winning the opportunities shifting from China.

\section{Conflicts of Interest}

The authors declare no conflicts of interest regarding the publication of this paper.

\section{References}

Adnan, A., Tumpa, A. S., \& Khan, M. M. (2020). Is Bangladesh Competent Enough to Confront Future Challenges? An Empirical Analysis of Competitiveness of Bangladesh's Apparel Sector Compared to Major Competitors. BGMEA University of Fashion and Technology. 
Ahmad, N., \& Kalim, R. (2014). Implications of Export Competitiveness, and Performance of Textile and Clothing Sector of Pakistan: Pre and Post Quota Analysis. Pakistan Journal of Commerce and Social Sciences (PJCSS), 8, 696-714.

Ahmed, R. (2013). An Analysis of the Change \& Volatility in the Apparel Industry of Bangladesh after MFA Era. Journal of Textile and Apparel Technology and Management (JTATM), 8, 1-11.

Ahmed, S. S., \& Mahmud, M. (2015). A Comparative Analysis on Banking Structures of China, Vietnam and Bangladesh. British Journal of Business Design \& Education, 8, 105-123.

Ahsan, M. F. (2020). Textile and Apparel Supply Chain during COVID 19: A Perspective from Bangladesh. University of Rhode Island.

Ali, A., Kabir, R., \& Uddin, S. (2017). Revealed Comparative Advantage and Competitiveness for RMG Industry of Bangladesh: A Pre and Post US-GSP Suspension Analysis. International Journal of Sustainable Development Research, 3, 54-62. https://doi.org/10.11648/j.ijsdr.20170306.11

Ali, M., Qun, W., \& Hossain, M. E. (2019). Revealed Comparative Advantage of Textile and Clothing Industry of Bangladesh in the North American Market. Journal of Business Management and Economic Research, 3, 28-42. https://doi.org/10.29226/TR1001.2019.100

Bradsher, K. (2008). Investors Seek Asian Options to Costly China. The New York Time.

Department for Inspection for Factories and Establishments (DIFE) (2016). Status of Building Assessment. DIFE.

Francisco, M. (2015). China's Rising Economy and the Power Struggle with the United States. California State University.

Grabher, G. (1993). The Weakness of Strong Ties; the Lock-In of Regional Development in the Ruhr Area. In G. Grabher (Ed.), The Embedded Firm: On the Socioeconomics of Industrial Networks (pp. 255-277). Routledge.

Hanson, T. R., Nguyen, G. V., \& Jolly, C. M. (2013). Comparative Advantages of the US Farm-Raised Catfish Industry: A Cross-Regional Analysis. Aquaculture Economics \& Management, 17, 87-101. https://doi.org/10.1080/13657305.2013.747228

Harrison, A. E. (1994). Productivity, Imperfect Competition and Trade Reform: Theory and Evidence. Journal of International Economics, 36, 53-73. https://doi.org/10.1016/0022-1996(94)90057-4

Hasan, M. Z., Asif, A. A. H., Rahaman, M. T., \& Akter, S. (2021). Effect of Super White Washing Process Temperature and Optical Brightening Agent Concentration on Various Properties of Stretch Denim Fabric. International Journal of Systems Engineering, 5, 43-50. https://doi.org/10.11648/j.ijse.20210501.16

Hossain, M. E., Dechun, H., \& Quangdung, T. (2013). Competitiveness of Textile and Apparel Industry of Bangladesh with China in International Trade. International Conference on Information, Business and Education Technology, March 2013, 722-727. https://doi.org/10.2991/icibet.2013.250

Islam, M. R., \& Maruf, K. N. (2014). Impact of EU GSP Facilities on Export Growth of Bangladesh: Especially on Readymade Garments Industry. Journal of Scientific and Technology Research, 3, 100-105.

Islam, M. S., Rakib, M. A., \& Adnan, A. (2016). Ready-Made Garments Sector of Bangladesh: Its Contribution and Challenges towards Development. Journal of Asian Development Studies, 5, 50-61. 
Jenkins, R., \& Sen, K. (2006). International Trade and Manufacturing Employment in the South: Four Country case STUDIES. Oxford Development Studies, 34, 299-322. https://doi.org/10.1080/13600810600921802

Joarder, M. A. M., Hossain, A. K. M. N., \& Hakim, M. M. (2010). Post-MFA Performance of Bangladesh Apparel Sector. International Review of Business Research Papers, 6, 134-144.

Kader, S., Maeen, M., \& Akter, K. (2014) Analysis of the Factors Affecting the Lead Time for Export of Readymade Apparels from Bangladesh; Proposals for Strategic Reduction of Lead Time. European Scientific Journal, 10, 268-283.

Kampelmann, S., Rycx, F., Saks, Y., \& Tojerow, I. (2018). Does Education Raise Productivity and Wages Equally? The Moderating Role of Age and Gender. IZA Journal of Labor Economics, 7, 1. https://doi.org/10.1186/s40172-017-0061-4

Khatun, R., \& Shamsuzzaman, M. (2017). Job Satisfaction of RMG Sectors in Bangladesh: A Study on Female Workers of AKH Group. International Journal of Humanities \& Social Science Studies (IJHSSS), 3, 97-106.

Kim, S. J., \& Choi, S. O. (2018). The Effects of Job Mismatch on Pay, Job Satisfaction, and Performance. Journal of Open Innovation: Technology, Market, and Complexity, 4, 49. https://doi.org/10.3390/joitmc4040049

Kukharyk, V. V. (2020). The US-China Trade War: Causes, Timeline and Possible Scenarios. Scientific Bulletin of the Lesia Ukrainka East European National University, 2, 26-36.

Maharani, T., \& Setiawan, M. (2019). The Relationship between Labor Wage and the Labor Productivity of the Indonesian Textile and Garment Industry (13 p.). EconPapers.

McCann, J. (2011). China's Textile and Apparel Industry and the Global Market: Five Competitive Forces. SAM Advanced Management Journal, 76, 33.

Meyer, N. I. (2004). Renewable Energy Policy in Denmark. Energy for Sustainable Development, 8, 25-35. https://doi.org/10.1016/S0973-0826(08)60388-9

Nuruzzaman, M., \& Haque, A. (2009). Lead Time Management in the Garment Sector of Bangladesh: An Avenues for Survival and Growth. European Journal of Scientific Research, 33, 617-629.

O'Connor, J. (2018). The Impact of Job Satisfaction on the Turnover Intent of Executive Level Central Office Administrators in Texas Public School Districts: A Quantitative Study of Work Related Constructs. Education Sciences, 8, 69. https://doi.org/10.3390/educsci8020069

Pham, T. Y., \& Yeo, G.-T. (2018). A Comparative Analysis Selecting the Transport Routes of Electronics Components from China to Vietnam. Sustainability, 10, 2444. https://doi.org/10.3390/su10072444

Rahaman, M. T., \& Islam, T. (2021a). Impacts and Possible Response Related to COVID-19 in the Textile and Apparel Industry of Bangladesh. Journal of management Science \& Engineering Research, 4, 9-15. https://doi.org/10.30564/jmser.v4i2.3166

Rahaman, M. T., Akter, S., \& Pranta, A. D. (2021b). Performance Optimization of Super White Washed Stretch Denim Fabric by Deviating Washing Process Time and Machine RPM. International Journal of Industrial and Manufacturing Systems Engineering, 10, 10-19. https://doi.org/10.11648/j.ijimse.20210601.13

Rahman, F. S. (2015). Effect of Post Multi Fiber Agreement-A Blessing for Bangladesh: Study of Survival Strategy. International Journal of Humanities, Arts and Social Sciences, 1, 92-100. https://doi.org/10.20469/ijhss.20006-2 
Rahman, K. M., \& Chowdhury, E. H. (2020). Growth Trajectory and Developmental Impact of Ready-Made Garments Industry in Bangladesh. In Bangladesh's Economic and Social Progress (pp. 267-297). Palgrave Macmillan.

https://doi.org/10.1007/978-981-15-1683-2 9

Setiawan, B. (2020). Does US-China Trade War Matter on ASEAN Stock Market: EventStudy Approach. Sriwijaya International Journal of Dynamic Economics and Business, 4, 161-174. https://doi.org/10.29259/sijdeb.v4i3.161-74

Shehab, M. (2018). US-China Trade War: Bangladesh's Golden Goose. LightCastle Analytics Wing.

Siddiqi, W., Ahmad, N., Khan, A. A., \& Yousef, K. (2012). Determinants of Export Demand of Textile and Clothing Sector of Pakistan: An Empirical Analysis, 16, 1171-1175.

Van der Eng, P. (2004). Productivity and Comparative Advantage in Rice Agriculture in South-East Asia since 1870. Asian Economic Journal, 18, 345-370. https://doi.org/10.1111/j.1467-8381.2004.00196.x

Yunus, M., \& Yamagata, T. (2012). The Garment Industry in Bangladesh. In T. Fukunishi (Ed.), Dynamics of the Garment Industry in Low-Income Countries: Experience of Asia and Africa. Interim Report, Chapter 6, IDE-JETRO.

Zhang, X., Wang, Z., \& Li, T. (2010). The Current Status of Occupational Health in China. Environmental Health and Preventive Medicine, 15, 263-270.

https://doi.org/10.1007/s12199-010-0145-2 